\title{
Full-scale collapse testing of a steel stiffened plate structure under cyclic axial-compressive loading
}

\author{
Jeom Kee Paik ${ }^{\mathrm{a}, \mathrm{b}, \mathrm{c}^{*}}$, Dong Hun Lee ${ }^{\mathrm{b}}$, Sung Hwan Noh ${ }^{\mathrm{b}}$, Dae Kyeom Park ${ }^{\mathrm{a}}$ and \\ Jonas W. Ringsberg ${ }^{\mathrm{d}}$ \\ ${ }^{a}$ The Korea Ship and Offshore Reseach Institute, Pusan National University (Lloyd's \\ Register Foundation Research Centre of Excellence), Busan, South Korea \\ ${ }^{\mathrm{b}}$ Department of Naval Architecture and Ocean Engineering, Pusan National \\ University, Busan, South Korea \\ ${ }^{\mathrm{c}}$ Department of Mechanical Engineering, University College London, London, UK \\ ${ }^{\mathrm{d} D e p a r t m e n t}$ of Mechanics and Maritime Sciences, Chalmers University of \\ Technology, Gothenburg, Sweden \\ * Corresponding author. J.K. Paik, Email. j.paik@ucl.ac.uk
}

\begin{abstract}
Plate panels of ships and floating offshore structures are likely subjected to cyclic loads arising from waves at sea. Depending on sea states, e.g., whipping in harsh sea states, the maximum amplitude of the cyclic loads may reach over $70 \%$ of ultimate loads. Of concerns is how the cyclic loads will affect the ultimate strength compared to a case of monotonically increasing loads. The aim of this paper is to experimentally investigate the ultimate strength characteristics of a steel stiffened plate structure under cyclic axial-compressive loading. A full-scale collapse testing in association with bottom structures of an as-built 1,900 TEU containership was conducted. It is concluded that the effects of cyclic loading on the ultimate compressive strength of steel stiffened plate structures are small as far as fatigue damages are not suffered due to the small number of load cycles. Details of the test database are documented, which will be useful to validate computational models for the ultimate strength analysis.
\end{abstract}

Keywords: Whipping, steel stiffened plate structures, full-scale collapse testing, cyclic axial-compressive loads, ultimate strength, ultimate limit states

\section{Introduction}

Stiffened panels are used in naval, offshore, mechanical, aerospace and civil engineering structures as primary strength members of ships, ship-shaped offshore installations, fuselages and bridges. The ultimate limit states are primary criteria for structural design and safety assessment, and they are usually evaluated considering that the external forces are increased monotonically until or after the maximum load-carrying capacity is unveiled [1,2]. In reality, however, ship and floating offshore structures while in service are likely subjected to cyclic loads arising from waves at seas and the maximum amplitude of cyclic loads may reach over $70 \%$ of ultimate loads in whipping [3]. Even if the structures may or may not reach the ultimate strength solely by cyclic loading, it is considered that the loading history and 
load effects associated with plastic deformations or local instability may reduce the maximum load-carrying capacity.

A number of studies on these issues are available in the literature. Yao and Nikolov [4] showed that cyclic loading may cause local failure in steel plates and thus the ultimate strength of plates can be reduced by the accumulated damages due to cyclic loading. Goto et al. [5] investigated the plastic buckling behaviour of steel plates under cycling loading. During late 1990s until recent years, a number of similar studies have been continued [6-12]. Very recently, Li et al. [13] proposed an analytical method to predict the ultimate strength behaviour of steel plates and stiffened panels under various patterns of cyclic loading. Jagite et al. [14] investigated dynamic ultimate strength behaviour of steel stiffened plate structures under more realistic scenarios of cyclic loading. In fact, this problem may also be associated with shakedown limit states $[15,24]$. Wave-induced hull girder loads depending on sea states can be predicted by probabilistic approaches [16] and used for structural response analysis [18]. Cyclic extreme loads can reduce welding-induced residual stresses [25], and they are associated with moving ice loads [26] or seismic loads arising from earthquake in jacket offshore structures [27].

Most of previous studies in the literature have been made by theoretical or numerical methods. Experimental studies have used small-scale models of plates or stiffened panels which cannot convert directly to full-scale prototypes in the ultimate strength behaviour for many reasons of scale effects such as welding-induced initial imperfections and other nonlinear effects associated with multiple physical processes, multiple scales and multiple criteria. Most of all, previous studies do not clearly resolve the issues - some studies argue that the effects of cyclic loading on the ultimate strength are negligible, while others indicate that cyclic loading can reduce the ultimate strength.

The objective of the present paper is to contribute to developing test database on the ultimate strength behaviour of a full-scale steel stiffened plate structure under cyclic axial-compressive loading. A full-scale substructure of an as-built containership carrying 1,900 TEU was tested. The test structure was constructed in a shipyard using exactly the same technique of welding as used in today's shipbuilding industry.

\section{Design of a full-scale steel stiffened plate structure}

Ship hull structures are repeatedly subjected to hogging or sagging in waves, and subsequently plate panels of hull structures develop axial compressive or tensile loads, as shown in Figure 1. In harsher sea states, the hogging or sagging moments may become large, e.g., in whipping at harsh sea states, and the plate panels may or may not buckle locally even if they may not reach the ultimate limit states. Having recognized that containerships in full load condition are in hogging [16] and subsequently bottom plate panels are subjected to axial compressive loads, the present study focused on a stiffened plate structure under cyclic axial-compressive loads in association with bottom structures of an as-built 1,900 TEU containership, as shown in Figure 2. 


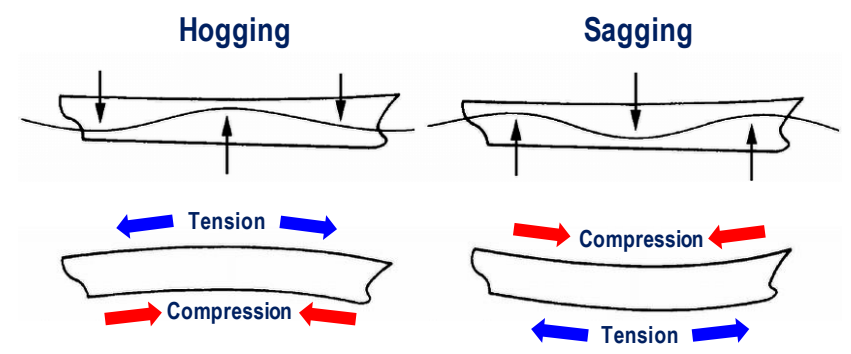

Figure 1. Cyclic axial-tensile or axial-compressive loads due to hogging or sagging in whipping condition of ships.
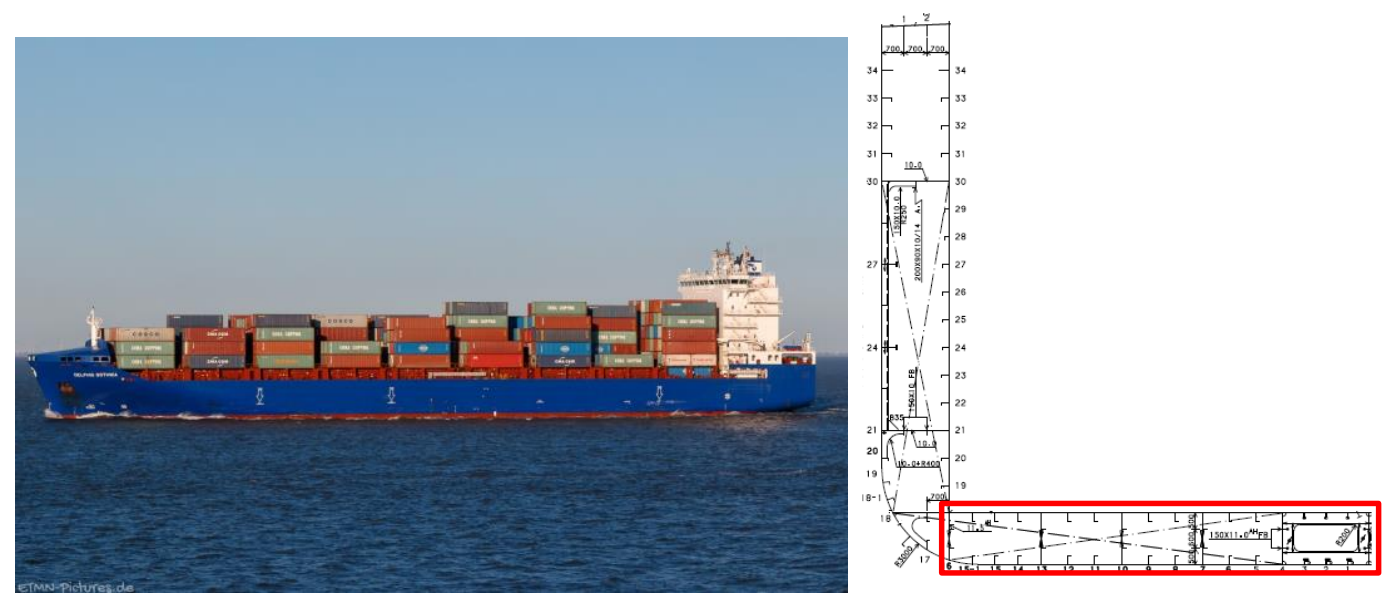

Figure 2. Plate panels in bottom structures of an as-built 1,900 TEU containership.
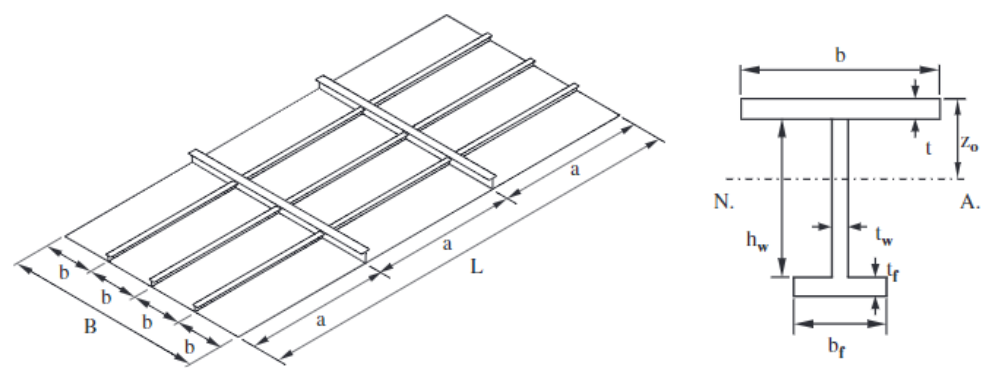

Figure 3. Nomenclature for a stiffened plate structure together with a support member.

Figure 3 denotes the nomenclature for a stiffened plate structure together with a support member. The properties of plate panels are defined by the plate slenderness ratio of plating, $\beta$, and the column slenderness ratio of longitudinal stiffeners with attached plating, $\lambda$, with the nomenclature shown in Figure 3 as follows:

$$
\begin{gathered}
\beta=\frac{b}{t} \sqrt{\frac{\sigma_{Y p}}{E}} \\
\lambda=\frac{a}{\pi r} \sqrt{\frac{\sigma_{Y e q}}{E}}
\end{gathered}
$$


where $a$ is the plate length (spacing between transverse frames), $b$ is the plate breadth (spacing between longitudinal stiffeners), $t$ is the plate thickness, $\sigma_{Y P}$ is the yield strength of plating, $\sigma_{Y e q}$ is the equivalent yield strength over the cross section of the stiffeners with attached plating which is given by

$$
\sigma_{Y e q}=\frac{b t \sigma_{Y p}+\left(h_{w} t_{w}+b_{f} t_{f}\right) \sigma_{Y S}}{b t+h_{w} t_{w}+b_{f} t_{f}}
$$

Here, $\sigma_{Y S}$ is the yield strength of stiffeners, $E$ is the Young's modulus, and $r=\sqrt{\frac{I}{b t+h_{w} t_{w}+b_{f} t_{f}}}$ is the radius of gyration for the stiffener with attached plating. The moment of inertia for the stiffener with attached plating, $I$, and the distance from the plate bottom to the neutral axis, $z_{o}$, are given by Equations (3a) and (3b), respectively. If the material yield strength for both plating and stiffeners is identical, then $\sigma_{Y p}=\sigma_{Y s}=\sigma_{Y}$ is taken.

$$
\begin{gathered}
I=\frac{b t^{3}}{12}+b t\left(z_{o}-\frac{t}{2}\right)^{2}+\frac{h_{w}^{3} t_{w}}{12}+h_{w} t_{w}\left(z_{o}-t-\frac{h_{w}}{2}\right)^{2}+\frac{b_{f} t_{f}^{3}}{12}+b_{f} t_{f}\left(t+h_{w}+\frac{t_{f}}{2}-z_{o}\right)^{2} \\
z_{o}=\frac{0.5 b t^{2}+h_{w} t_{w}\left(t+0.5 h_{w}\right)+b_{f} t_{f}\left(t+h_{w}+0.5 t_{f}\right)}{b t+h_{w} t_{w}+b_{f} t_{f}}
\end{gathered}
$$

It is of interest to survey the properties of plate panels in as-built containership structures. Tables 1 and 2 present the plate slenderness ratio and the column slenderness ratio of plate panels in as-built containership structures. Figure 4 plots their values with the containership size. Plate panels studied in the survey include longitudinal bulkhead, side shell, inner bottom, and outer bottom. It is observed that the panel properties are allocated in a similar value at the same locations of plate panels regardless of the size of the ships. In particular, the properties of plate panels in bottom structures under consideration in the present paper are in the range of 1.70 to 3.68 for $\beta$, and 0.24 to 1.92 for $\lambda$.

Table 3 presents the dimensions and their properties for plate panels at bottom structures of an as-built containership carrying 1,900 TEU. The plate panels are made of high tensile steel with grade AH32 for both plating and stiffeners with a (nominal) yield strength of $315 \mathrm{MPa}$, where the plate slenderness ratio is 2.89 and the column slenderness ratio is 0.38 .

Calculations using the ALPS/ULSAP [17] program shows that the plate panels under axial compressive loads reach the ultimate strength with the collapse mode $\mathrm{V}$ (tripping of stiffeners), while a total of six collapse modes are pertinent in stiffened 
plate panels [1]. The test structure that could be handled by the test facility was designed so that the dimensions and their properties are similar to those of the as-built ship as indicated in Table 3. Figure 5 presents the drawing of the test structure which was provided to the shipyard for its fabrication.

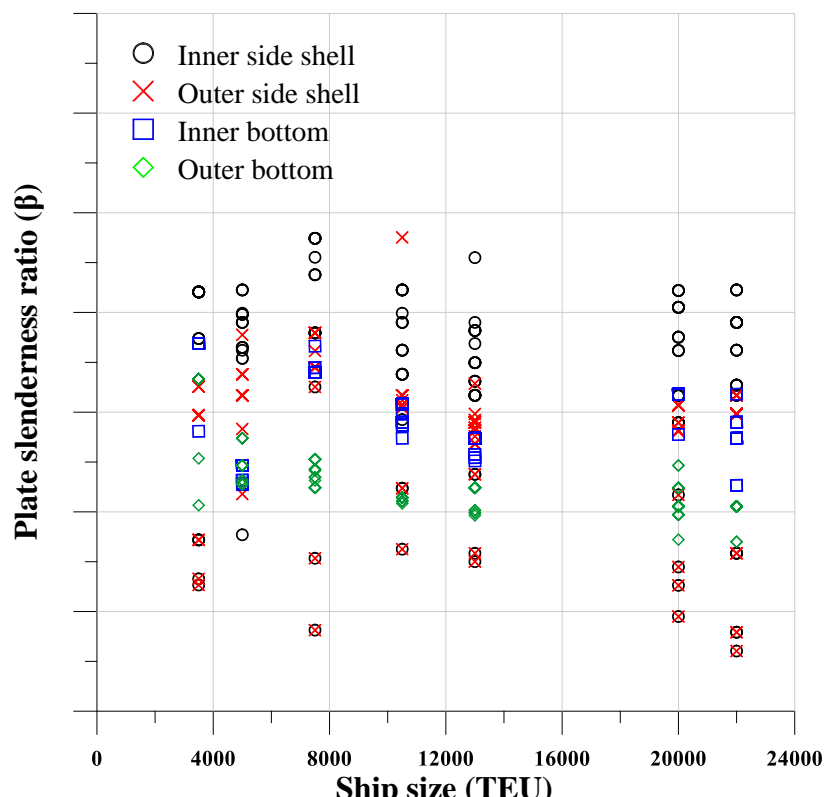

(a)

Ship size (TEU)

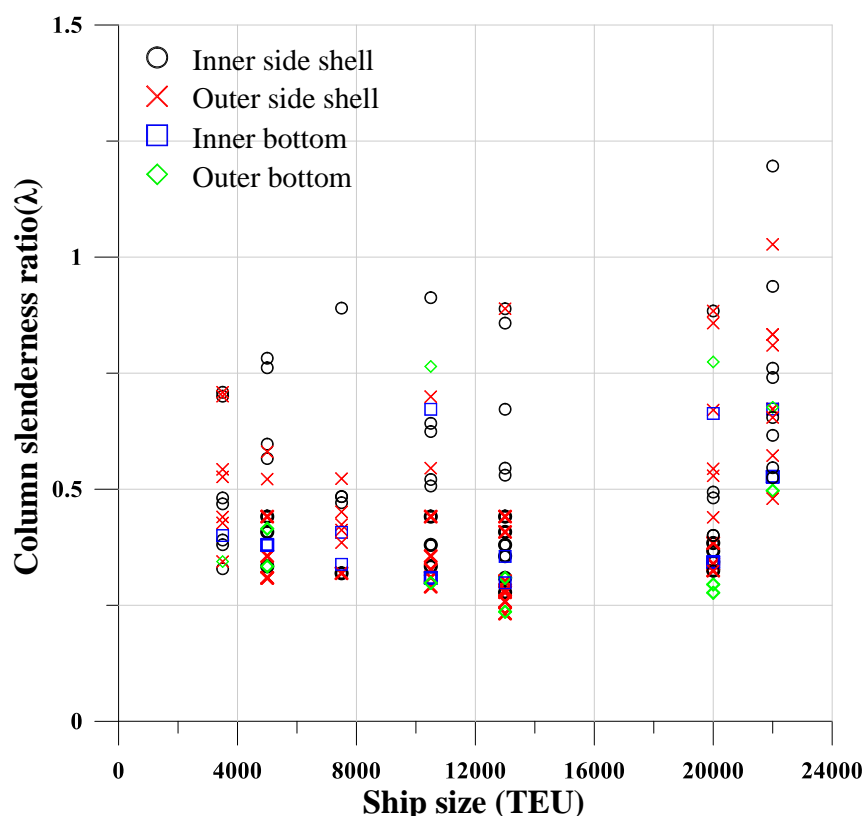

(b)

Ship size (TEU)

Figure 4. Distribution of the geometric properties of plate panels with the size of as-built containerships, (a) Plate slenderness ratio $\beta$, (b) Column slenderness ratio $\lambda$ 
Table 1. Survey of the plate slenderness ratio of plate panels in as-built containership structures.

\begin{tabular}{|c|c|c|c|}
\hline \multirow{2}{*}{ Location } & \multicolumn{3}{|c|}{ Plate slenderness ratio, $\beta$} \\
\cline { 2 - 4 } & Minimum & Maximum & Average \\
\hline $\begin{array}{c}\text { Longitudinal } \\
\text { bulkhead }\end{array}$ & 0.60 & 4.74 & 3.47 \\
\hline Side shell & 0.60 & 4.74 & 2.87 \\
\hline Inner bottom & 2.27 & 3.68 & 2.97 \\
\hline Outer bottom & 1.70 & 3.33 & 2.28 \\
\hline
\end{tabular}

Table 2. Survey of the column slenderness ratio of plate panels in as-built containership structures.

\begin{tabular}{|c|c|c|c|}
\hline \multirow{2}{*}{ Location } & \multicolumn{3}{|c|}{ Column slenderness ratio, $\lambda$} \\
\cline { 2 - 4 } & Minimum & Maximum & Average \\
\hline $\begin{array}{c}\text { Longitudinal } \\
\text { bulkhead }\end{array}$ & 0.28 & 1.23 & 0.55 \\
\hline Side shell & 0.23 & 1.03 & 0.51 \\
\hline Inner bottom & 0.30 & 1.67 & 0.60 \\
\hline Outer bottom & 0.24 & 1.92 & 0.68 \\
\hline
\end{tabular}

Table 3. Dimensions of the reference versus tested structures.

\begin{tabular}{|l|l|l|}
\hline \multicolumn{1}{|c|}{ Parameter } & \multicolumn{1}{|c|}{ Reference structure } & \multicolumn{1}{c|}{ Tested structure } \\
\hline Material & AH32 & AH32 \\
\hline Length of plate panel, $L$ & $9450 \mathrm{~mm}$ & $9450 \mathrm{~mm}$ \\
\hline $\begin{array}{l}\text { Spacing between } \\
\text { transverse frames, } a\end{array}$ & $3150 \mathrm{~mm}$ & $3150 \mathrm{~mm}$ \\
\hline Breadth of plate panel, $B$ & $2640 \mathrm{~mm}$ & $2640 \mathrm{~mm}$ \\
\hline $\begin{array}{l}\text { Spacing between } \\
\text { longitudinal stiffeners, } b\end{array}$ & $864 \mathrm{~mm}$ & $720 \mathrm{~mm}$ \\
\hline Plate thickness, $t$ & $12 \mathrm{~mm}$ & $10 \mathrm{~mm}$ \\
\hline \begin{tabular}{l} 
Plate slenderness ratio, $\beta$ \\
\hline $\begin{array}{l}\text { Dimensions of } \\
\text { longitudinal stiffener }(\mathrm{s}),\end{array}$
\end{tabular} & 2.89 & 2.89 \\
$h_{w} \times b_{f} \times t_{w} / t_{f}$ & $283 \times 90 \times 13 / 17(\mathrm{~T})(\mathrm{mm})$ & $290 \times 90 \times 10 / 10(\mathrm{~T})(\mathrm{mm})$ \\
\hline $\begin{array}{l}\text { Dimensions of transverse } \\
\text { frame }(\mathrm{s}), h_{w} \times b_{f} \times t_{w} / t_{f}\end{array}$ & $665 \times 150 \times 10 / 10(\mathrm{~T})(\mathrm{mm})$ & $665 \times 150 \times 10 / 10(\mathrm{~T})(\mathrm{mm})$ \\
\hline $\begin{array}{l}\text { Column slenderness ratio, } \\
\lambda\end{array}$ & 0.38 & 0.38 \\
\hline \begin{tabular}{l} 
Mass of test structure \\
\hline
\end{tabular} & 4.670 ton & 3.994 ton \\
\hline
\end{tabular}




\begin{tabular}{|l|l|l|}
\hline Collapse mode & Tripping of stiffeners & Tripping of stiffeners \\
\hline $\begin{array}{l}\text { Ultimate compressive } \\
\text { strength predicted by } \\
\text { ALPS/ULSAP }\end{array}$ & $238.94 \mathrm{MPa}$ & $225.96 \mathrm{MPa}$ \\
\hline
\end{tabular}

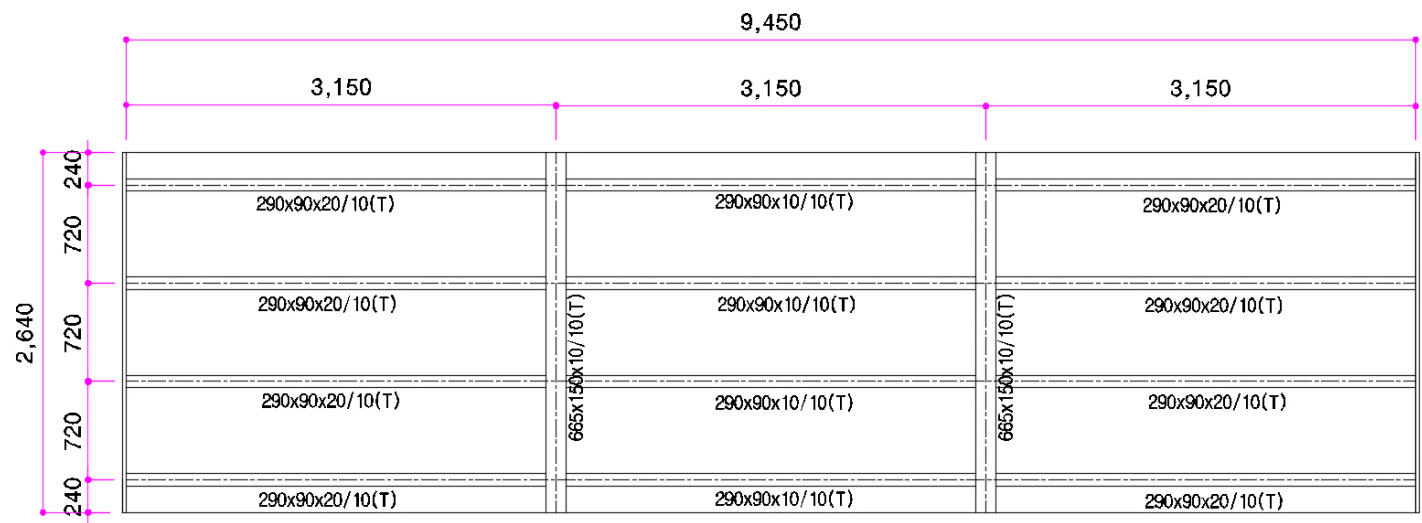

Figure 5. Dimensions of the tested structure (unit: $\mathrm{mm}$ ).

\section{Fabrication of the test structure}

The test structure was fabricated by a shipyard in Busan, South Korea, which usually builds small and medium sized ships for trading cargoes and patrolling along coastlines. After material procurement of high tensile steel with grade AH32 was completed, tensile coupon test specimens were extracted from the steel sheet as per the specification of ASTM (American Society for Testing and Material) E8 [18], as shown in Figure 6.
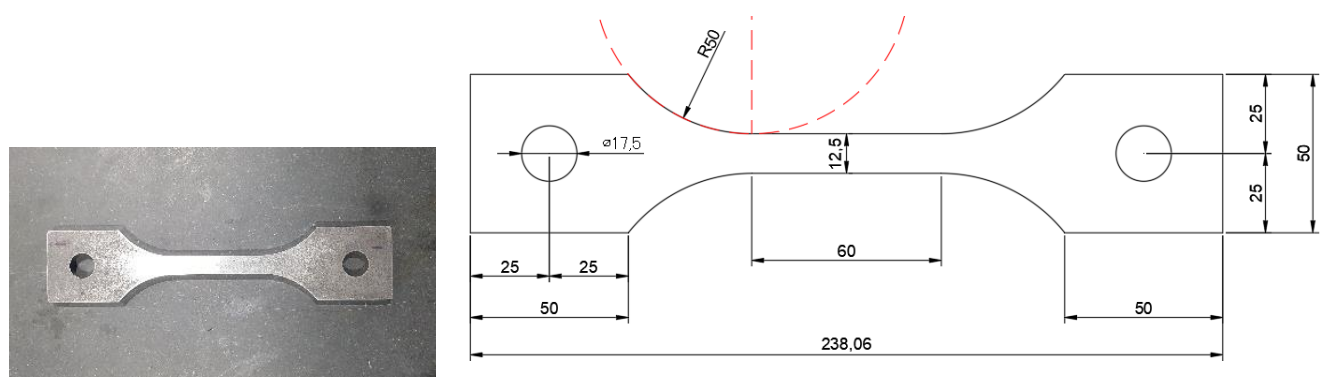

Figure 6. Tensile coupon test specimen of the material AH32.

Figure 7 shows the engineering stress-engineering strain curves of the material AH32 which was used for fabrication of the test structure, where three specimens were tested. Table 4 provides the mechanical properties of the material AH32 at RT (room temperature at $20^{\circ} \mathrm{C}$ ), obtained from tensile coupon tests in the present study. Figure 8 shows the test structure during the fabrication in the shipyard. 


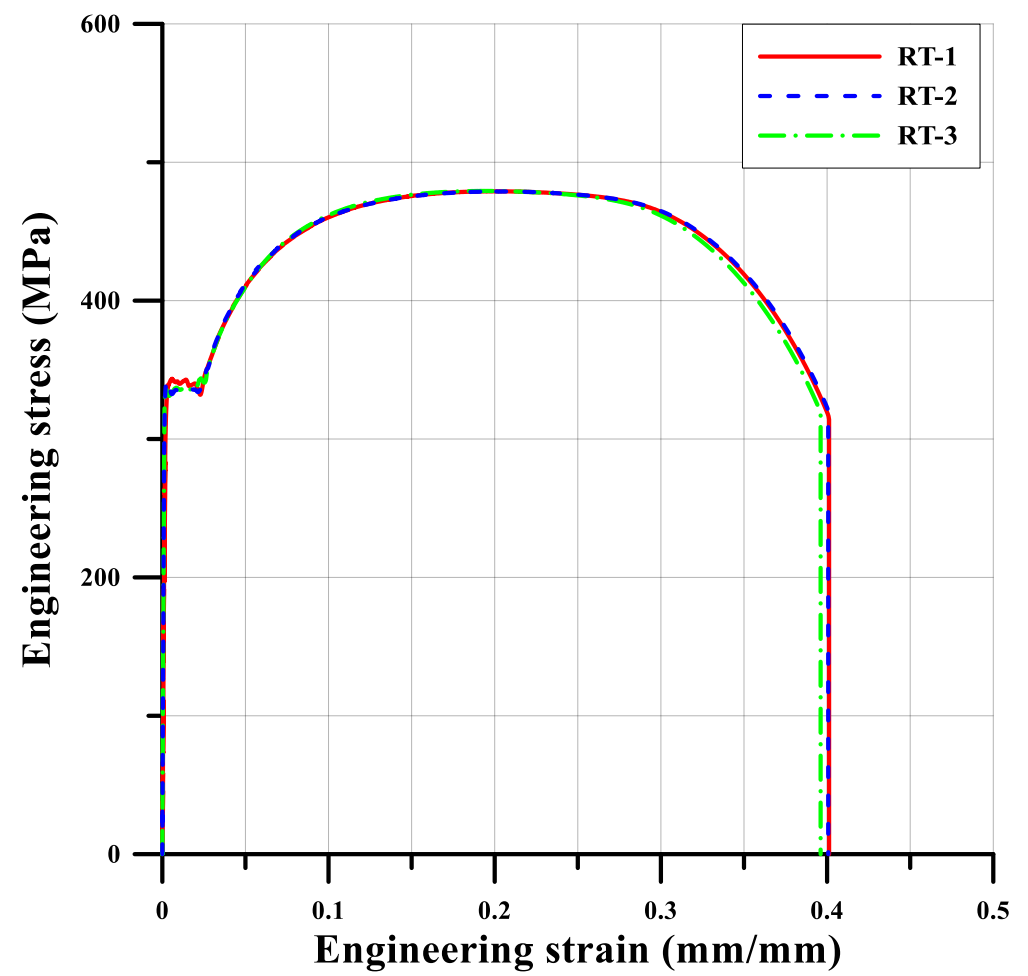

Figure 7. Engineering stress-engineering strain curve of the material AH32 at room temperature $\left(20^{\circ} \mathrm{C}\right)$ obtained from the tensile coupon tests.

Table 4. Mechanical properties of the material AH32 obtained from tensile coupon tests.

\begin{tabular}{|c|c|c|c|c|}
\hline Specimen & $E(\mathrm{GPa})$ & $\sigma_{Y}(\mathrm{MPa})$ & $\sigma_{T}(\mathrm{MPa})$ & $\varepsilon_{f}(\%)$ \\
\hline RT-1 & 205.8 & 332.0 & 479.0 & 40.1 \\
\hline RT-2 & 205.8 & 332.4 & 478.9 & 40.1 \\
\hline RT-3 & 205.8 & 331.1 & 479.3 & 39.6 \\
\hline Average & 205.8 & 331.8 & 479.1 & 39.9 \\
\hline
\end{tabular}

Note: $\sigma_{T}=$ ultimate tensile strength, $\varepsilon_{f}=$ failure (fracture) strain.

Table 5. Welding condition for the fabrication of the test structure.

\begin{tabular}{|l|l|}
\hline Weld method & FCAW \\
\hline Flux-cored wire & CSF-71S \\
\hline Leg length & $7 \mathrm{~mm}$ \\
\hline Current & $260 \mathrm{~A}(225 \sim 275 \mathrm{~A})$ \\
\hline Voltage & $28 \mathrm{~V}(23 \sim 32 \mathrm{~V})$ \\
\hline Welding speed & $30 \mathrm{~cm} / \mathrm{min}(24 \sim 34 \mathrm{~cm} / \mathrm{min})$ \\
\hline Heat input & $14.56 \mathrm{KJ} / \mathrm{cm}(7 \sim 18 \mathrm{KJ} / \mathrm{cm})$ \\
\hline
\end{tabular}

Note: The value in the parenthesis indicates the range of the requirements which should be met in welding. 
Exactly the same technology of welding as used for fabrication of real ship structures was applied. The steel sheet was procured with one big plate so that no butt welds were needed to connect multiple pieces of plates. Fillet welds were made to attach support members to the plating as per the welding requirements of DNV-GL [19]. The FCAW (flux-cored arc welding) technique was used in accordance with the welding procedure specification (WPS) requirements as indicated in Table 5.
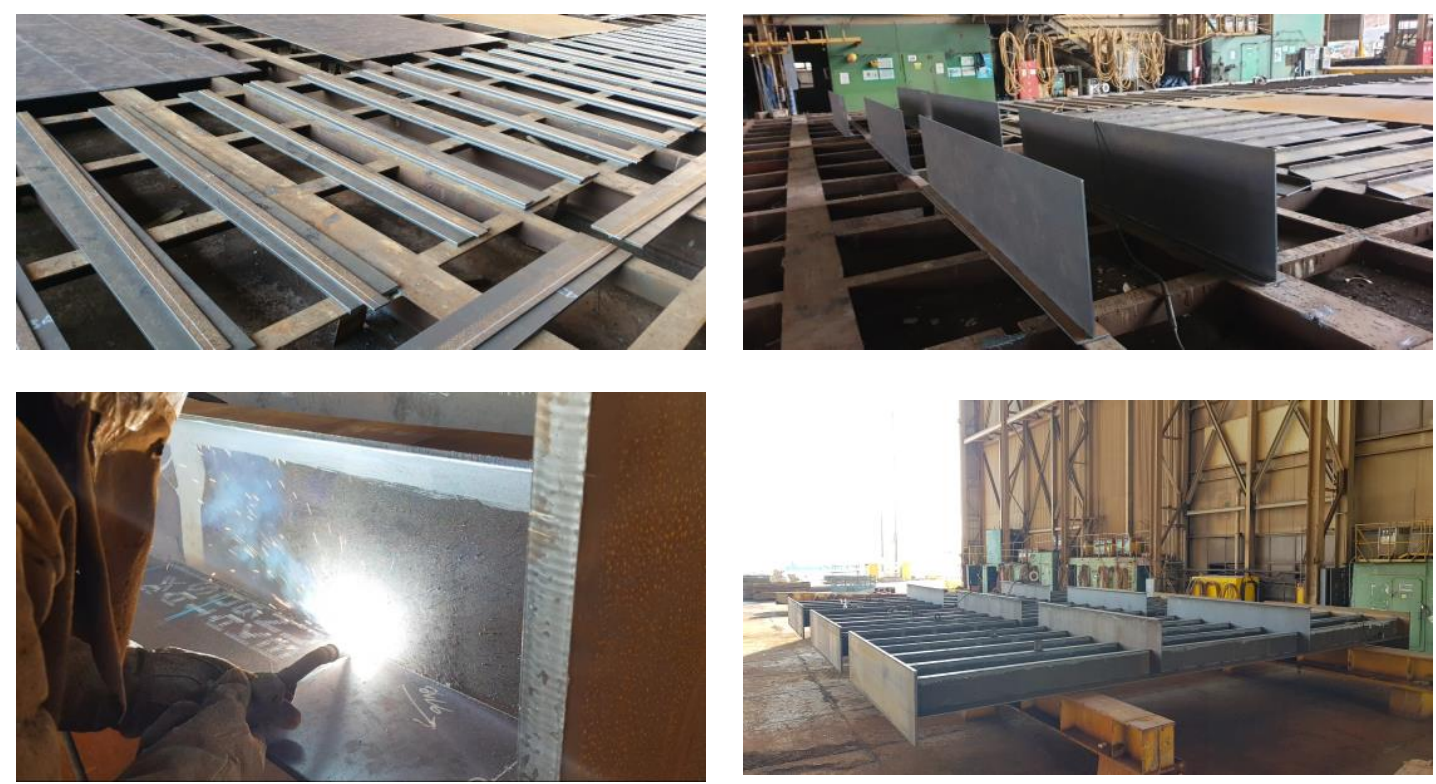

Figure 8. The test structure during the fabrication in a shipyard.

\section{Measurements of Welding-Induced Initial Imperfections}

Welding induces initial imperfections in the form of initial deformations and residual stresses which significantly affect the ultimate limit states of structures, and thus their magnitudes and shapes were measured after completing the construction of the test structure. Details of the measurement results together with methods of numerical predictions are reported in $\mathrm{Yi}$ et al. [20, 21]. In this paper, the results are briefly presented.

Modern technologies for measuring the initial imperfections are employed. The 3D laser scanner was used as a non-contact method providing relatively stable and accurate data in a wide range of large-sized structures [2]. Figure 9 shows the measured data of the plate initial deflections over the cross-section A-A' of the test structure. Also, X-ray diffraction (XRD) method as one of the non-destructive examination techniques was used to measure the residual stresses [2]. Figure 10 shows the measured data of welding-induced residual stresses in plating. It is observed that tensile residual stresses develop at the heat-affected zone of welding, while compressive residual stresses develop in the middle of plating to fulfil equilibrium between tensile and compressive residual stress blocks. This observation is quite similar to existing studies [1, 22, 23]. 

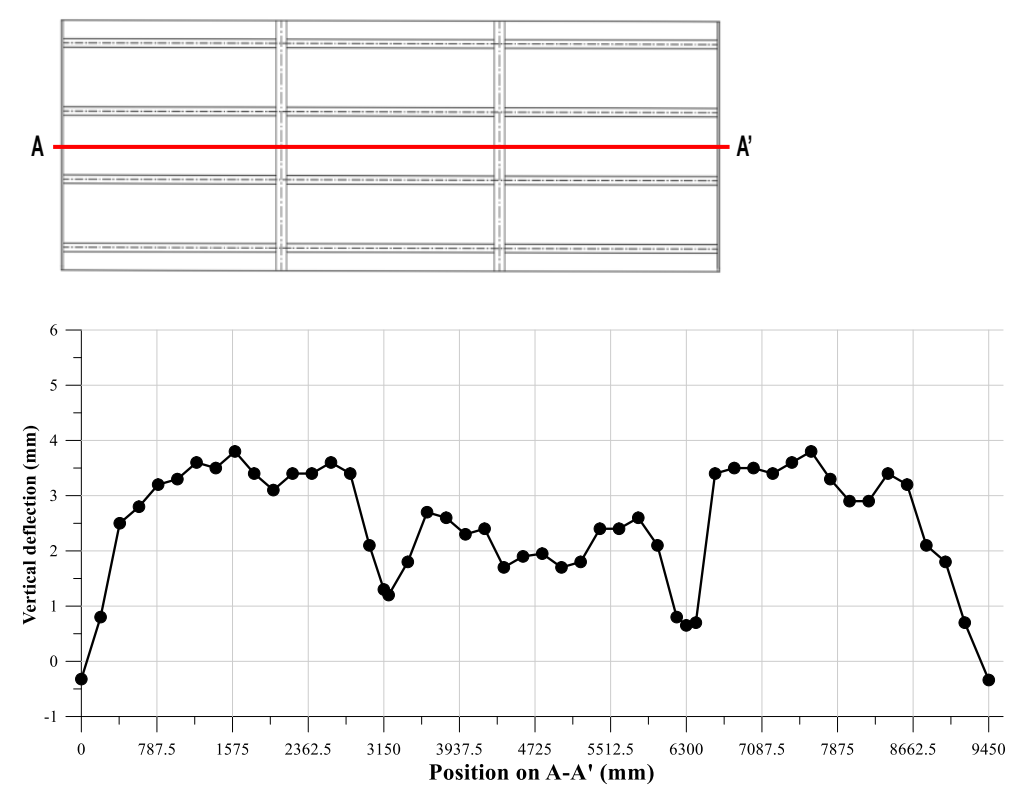

Figure 9. Measured data of the plate initial deflection over the cross-section A-A' of the test structure.

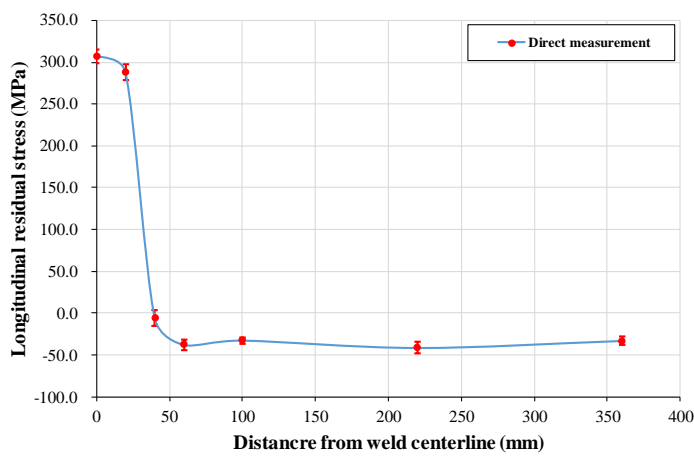

(a)

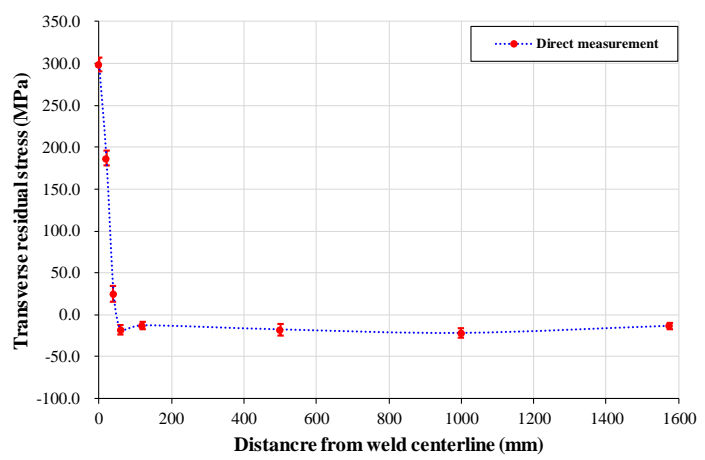

(b)

Figure 10. Measured data of the welding-induced residual stress in plating: (a) longitudinal direction, (b) transverse direction.

\section{Test Set-up}

\subsection{Test Frame and Jigs}


Figure 11 shows the layout of test set-up with a specially designed rig which makes possible to perform a large scale physical model testing. The test was conducted at the ICASS/KOSORI test site (www.icass.center) in Hadong, South Korea. As shown in Figure 12, the axial compressive loads were provided by two hydraulic actuators (among three at the test facility) which were fixed on a reaction wall. Each loading actuator can carry up to 1,000 tons in compression. The 'rigid-body' jig helped achieve the application of a uniformly distributed compressive loading over the loaded edge, which assigned fixed boundary conditions except for the moving direction of the actuators. The other end of the test structure was fixed by a reaction wall. The two hydraulic actuators can apply a maximum of 2,000 tons in total with axial compressive or tensile loads, i.e., 1,000 tons for each actuator. A personal computer controlled the synchronizing of the two actuators so that the uniform loads were applied over the loaded edge.

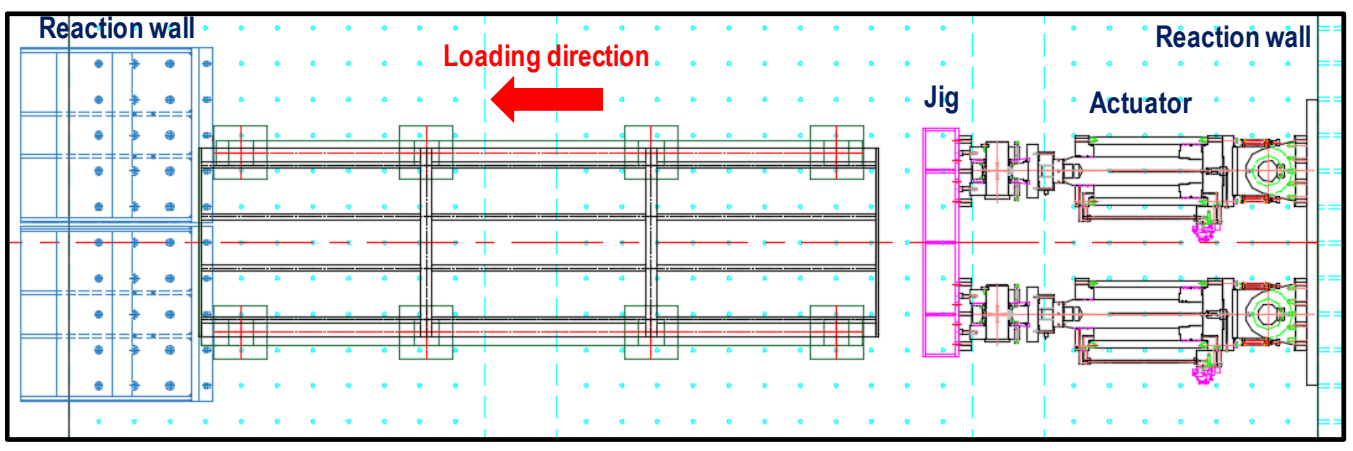

(a) Plan view of the test set-up

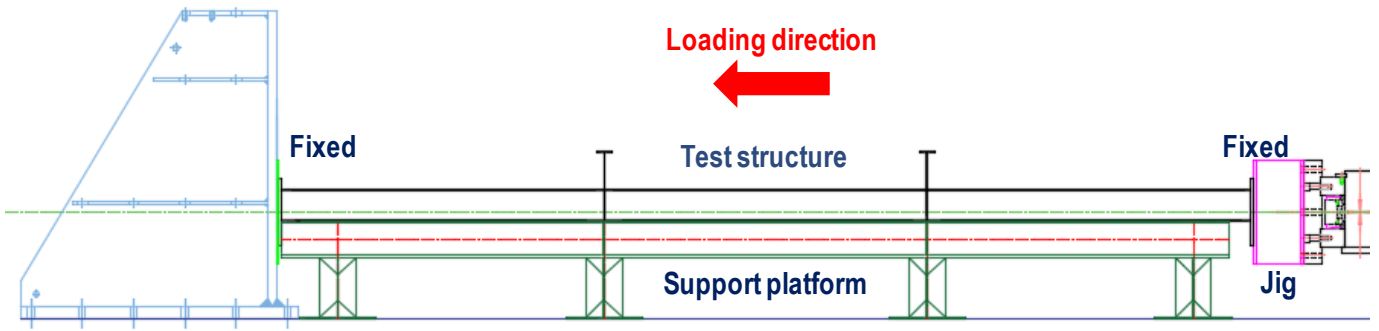

(b) Profile view of the test set-up

Figure 11. Layout of the test set-up with the two hydraulic loading actuators and the reaction wall . 


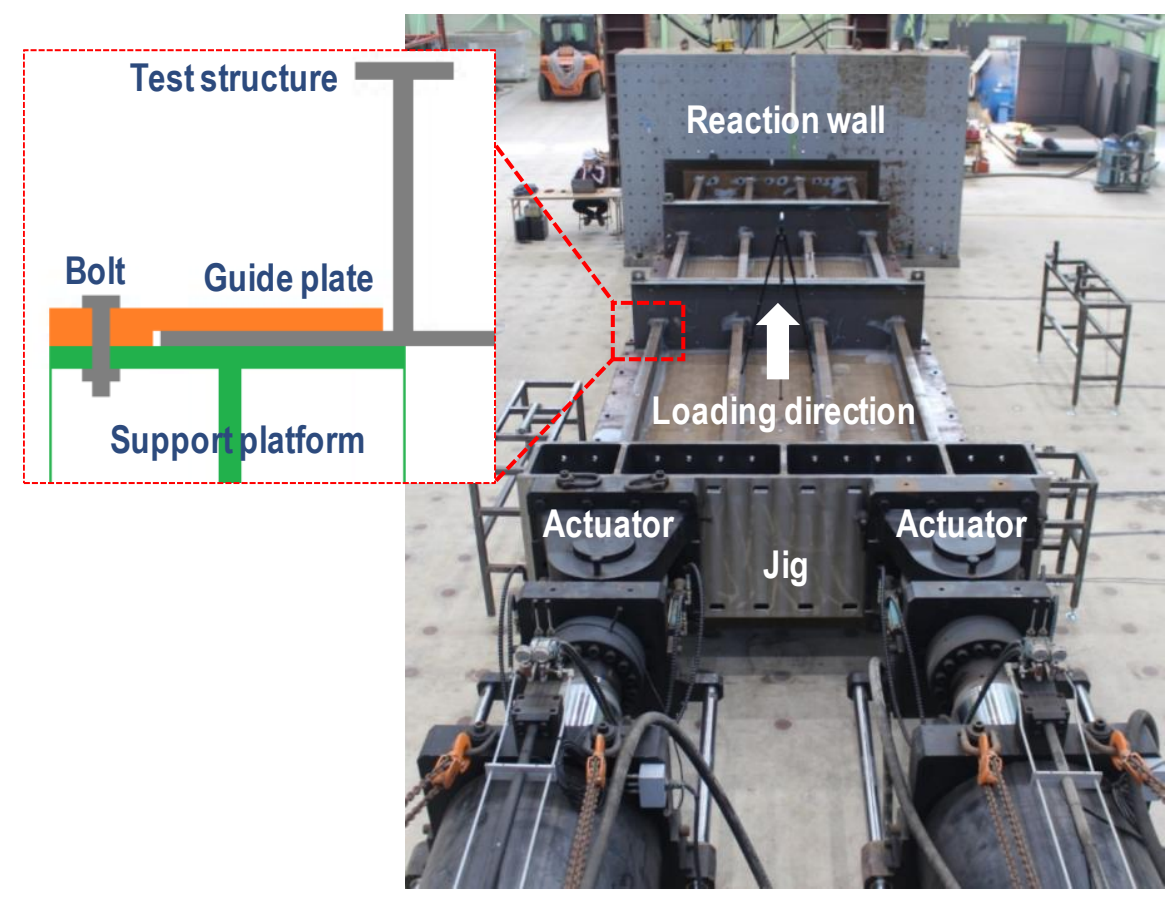

Figure 12. Specially designed test rig at the ICASS/KOSORI test site.

The test structure was placed on the rigid support platform and both of unloaded edges were supported by guide plates, as shown in Figure 12. This test set-up intended to allow in-plane movements of the structure during testing while constraining the vertical deformations (lateral deflections) along the unloaded edges. To minimize unnecessary frictions between two contacting plate-surfaces, lubricants were applied to each contact surface of plating with supporting jigs.

\subsection{Application of Cyclic Axial-Compressive Loading}

The experiment was displacement-controlled and the applied load history with time was registered by load cells in the actuators. Axial compressive loading (without tensile loading) with a load ratio of tension to compression with $\mathrm{R}=0$ was repeatedly applied where the displacement (i.e., axial-compressive loading) was monotonically increased until the desired magnitude was reached and then it was removed. As shown in Figure 13, a total of six loading steps were applied with varying the magnitude of the maximum loads at each step, as indicated in Table 6. At the final step (step 6), the loading was applied until and after the ultimate limit states were reached. The loading speed was slow with $0.25 \mathrm{~mm} / \mathrm{s}$ which may be regarded as a quasi-static condition. 


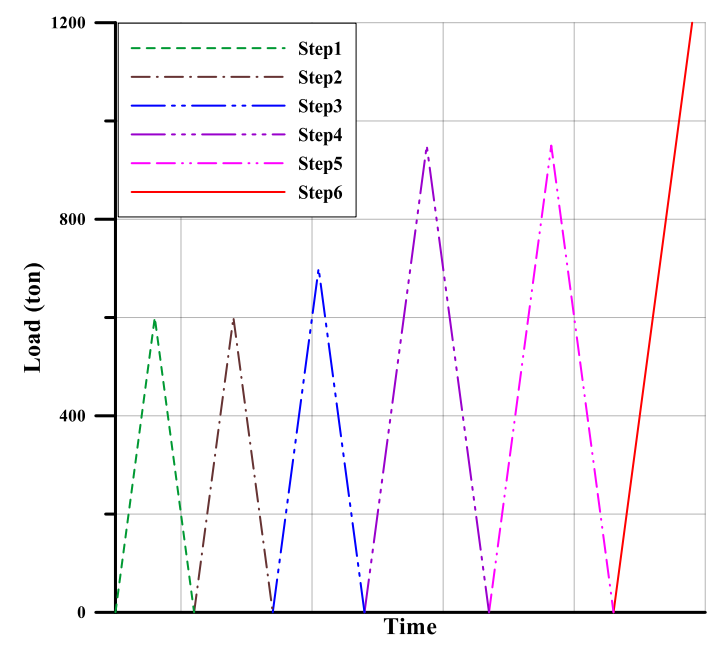

Figure 13. Cyclic axial-compressive loading at each loading step.

Table 6. Target load for each loading step

\begin{tabular}{|c|c|}
\hline $\begin{array}{c}\text { Loading step } \\
\text { No. }\end{array}$ & Target load (ton) \\
\hline Step 1 & 600 \\
\hline Step 2 & 600 \\
\hline Step 3 & 700 \\
\hline Step 4 & 950 \\
\hline Step 5 & 950 \\
\hline Step 6 & $\begin{array}{c}\text { Until and after the ultimate } \\
\text { strength was reached }\end{array}$ \\
\hline
\end{tabular}

\subsection{Acquisition of Test Data}

As the loading was applied, deformations of plating and support members as well as the axial shortening of the test structure were measured by sensors and recorded by a personal computer. Figure 14 shows the measuring points of the loads and deformations in the tested structure. A total of thirteen linear variable differential transformer (LVDT) sensors were mounted below the tested structure (on the floor side) to measure the lateral (vertical) deflection of plating. The sideways (transverse) deformations of the longitudinal stiffeners were also measured using two wired LVDT sensors which were placed on flange of the longitudinal stiffener. The load cells attached on each hydraulic actuator measured the history of cyclic axial-compressive loads with time. 


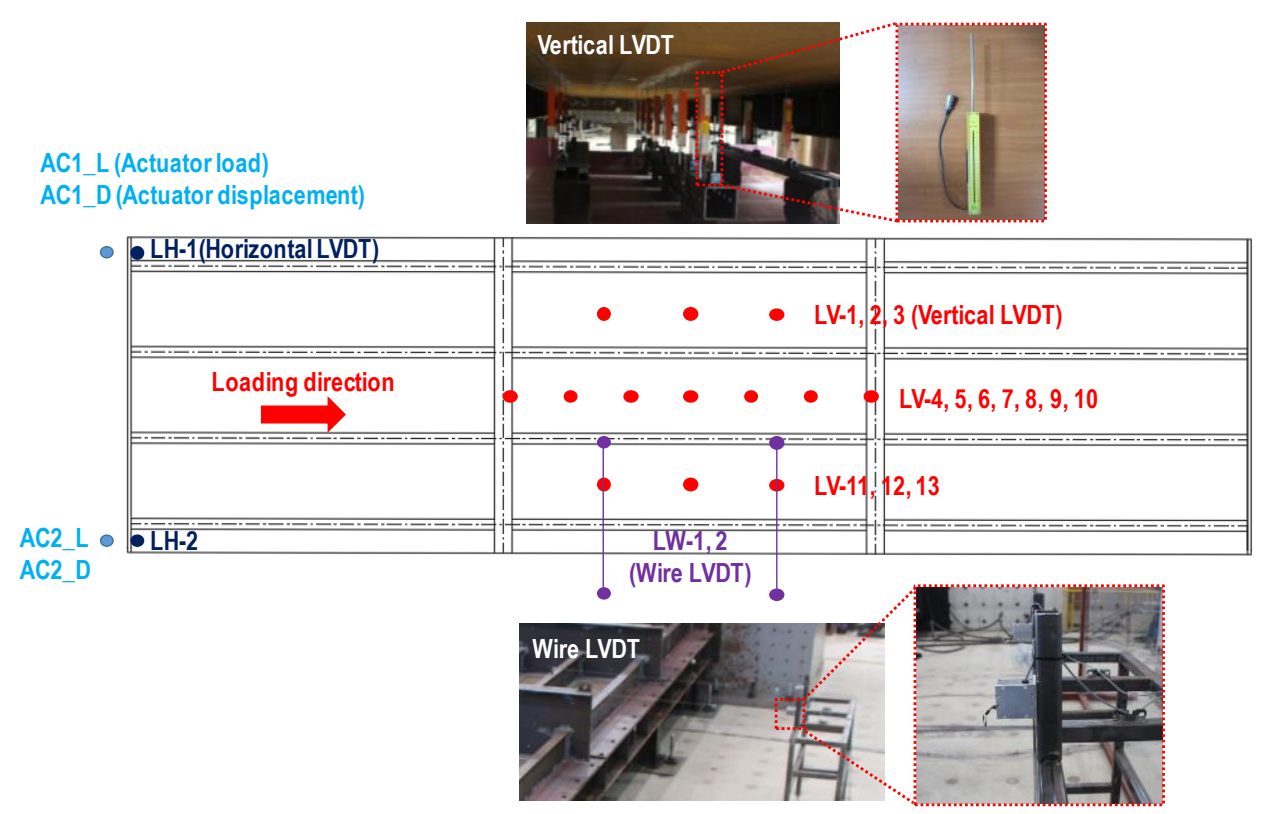

Figure 14. Measuring points of loads and displacements in the tested structure.

\section{Test Results and Discussion}

Figure 15 shows the axial-compressive load versus time history (for a load ratio $R$ of tension to compression to tension with $\mathrm{R}=0$ ) and the axial shortening versus time curve during the testing. Table 7 provides details of the load application at each step which was recorded by a personal computer.

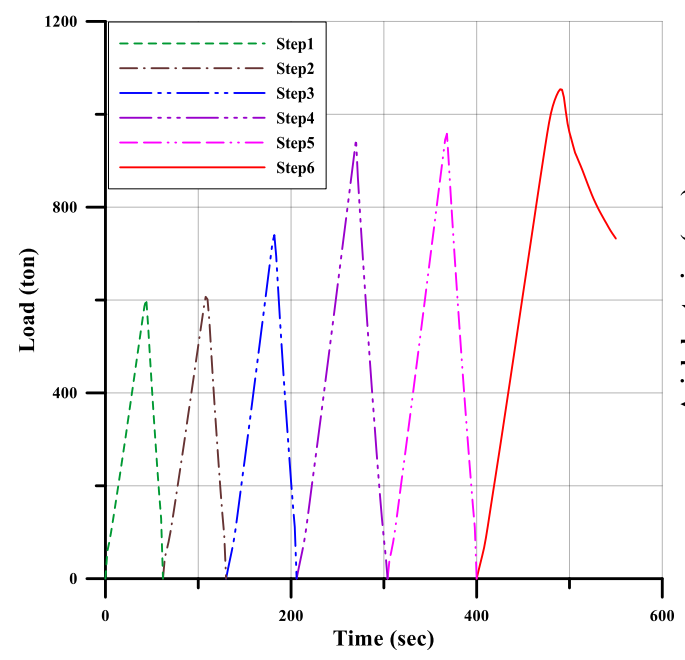

(a) Load-time curve

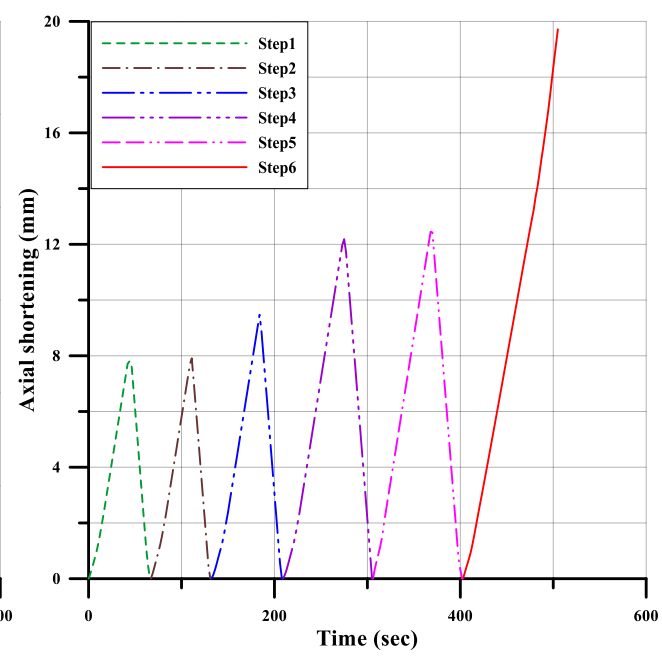

(b) Axial shortening-time curve

Figure 15. Cyclic axial-compressive load and axial shortening of the tested structure with time. 
Table 7. Recorded data of load application at each step.

\begin{tabular}{|c|c|c|c|}
\hline Loading step No. & Load (ton) & $\begin{array}{c}\text { Axial shortening } \\
(\mathrm{mm})\end{array}$ & $\begin{array}{c}\text { In-plane stiffness } \\
\text { (ton/mm) }\end{array}$ \\
\hline Step 1 & 601.59 & 7.80 & 76.53 \\
\hline After unloading & 3.24 & 0.1 & - \\
\hline Step 2 & 609.58 & 7.91 & 76.37 \\
\hline After unloading & -2.52 & -0.1 & 76.15 \\
\hline Step 3 & 726.68 & 9.90 & - \\
\hline After unloading & 4.21 & 0.1 & 75.49 \\
\hline Step 4 & 945.90 & 12.98 & - \\
\hline After unloading & -0.22 & 0.0 & - \\
\hline Step 5 & 958.12 & 13.01 & 72.36 \\
\hline After unloading & -1.90 & -0.1 & 16.40 \\
\hline Step 6 & 1054.04 & &
\end{tabular}

By combining both Figures 15(a) and 15(b) at identical time steps, the axial compressive load versus axial shortening curve was obtained as shown in Figure 16. Table 7 provides in-plane stiffness of the test structure at each loading step. It is obvious that the in-plane stiffness tends to decrease as the number of load cycles increases. This may be due to the fact that some local member failures (including local plasticity) have been accumulated and expanded with load cycles. However, the reduction of the in-plane stiffness was found to be small regardless of the magnitude of load applications, where the difference of the in-plane stiffness between step 1 and step 6 (final step) is at most $5.4 \%$. The maximum load-carrying capacity (ultimate strength) was found to be 1,054 tons at an axial shortening of $16.40 \mathrm{~mm}$. Figure 17 shows the deformed shape of the test structure after the testing was finished. It is seen that the structure has reached by tripping of stiffeners or collapse mode $\mathrm{V}$ as previously predicted by ALPS/ULSAP [17].

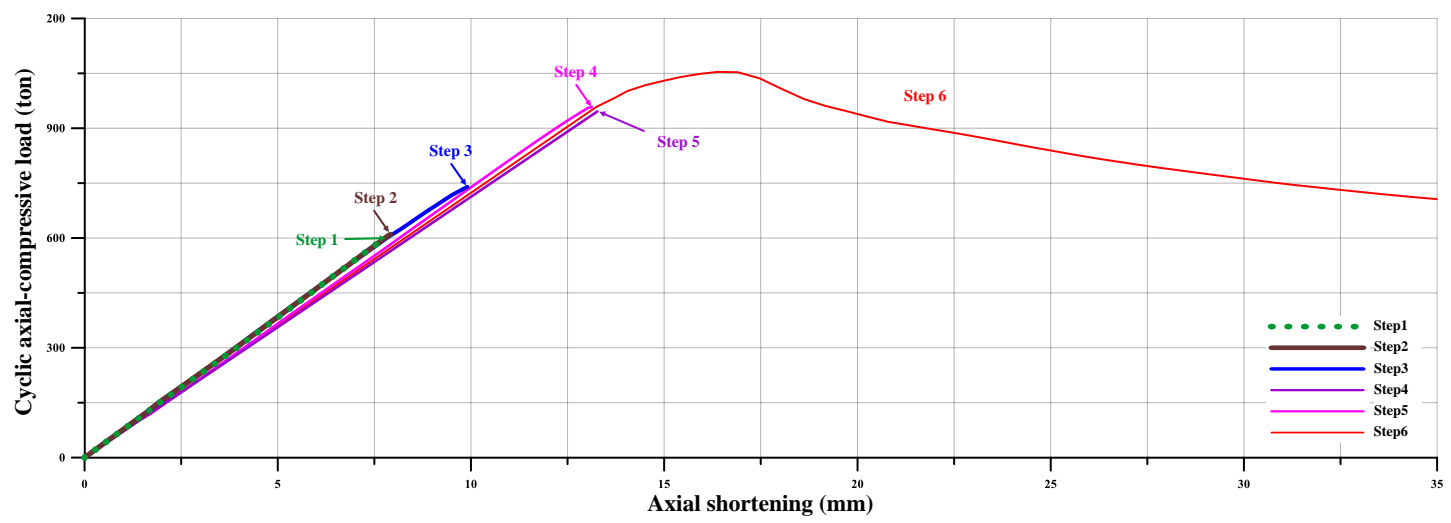

Figure 16. Cyclic axial-compressive load versus axial shortening curve of the tested structure. 


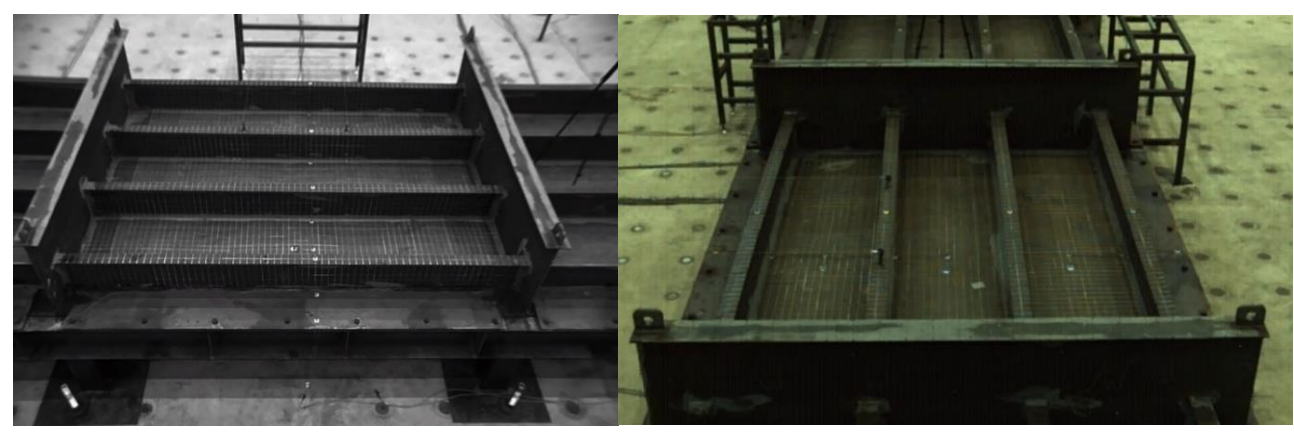

(a) Initial status

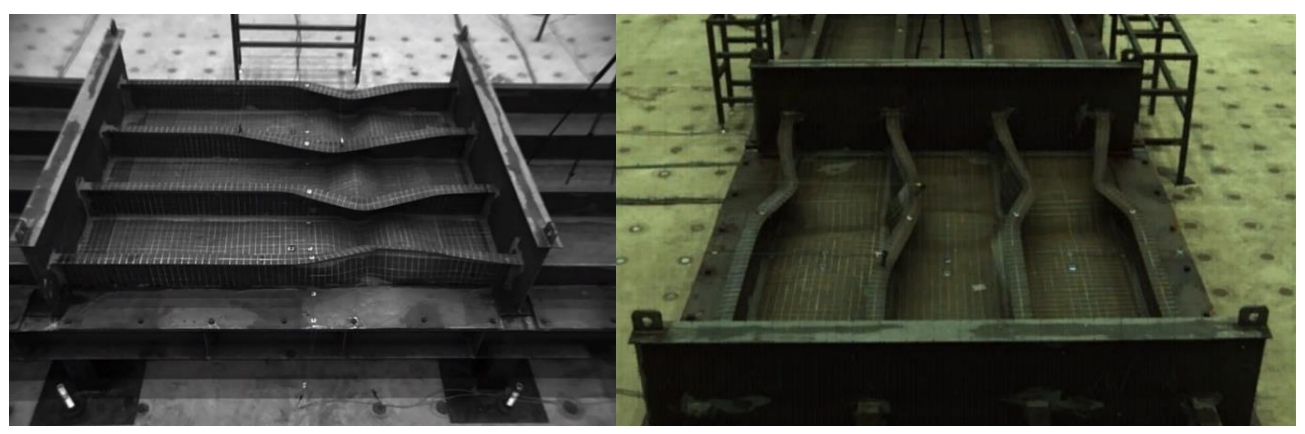

(b) After collapse

Figure 17. The tested structure before and after the testing.

Figure 18 shows the plate deflection at the maximum load of each step. The maximum deflection of plating at the ultimate load was $12.30 \mathrm{~mm}$, occurring at the center of the plate. It is found that the plate buckling half-wave number is different with 2, 3 or 4 for the plating regardless of the same plate aspect ratio. This may be due to the difference of the initial deflection shape in each plate. Figure 19 shows the plate deflection of the tested structure at each loading step. After the unloading process was completed at each loading step, it is found that the permanent deflection was very small, with less than $1 \mathrm{~mm}$. This means that the behaviour of the tested structure remained in almost elastic regime without significant permanent deformations as elastic deformations are almost entirely reversed during the unloading or cyclic loading. It is concluded that the cyclic loading applied to the test structure does not affect the ultimate strength behaviour of plating significantly as far as fatigue cracking is not suffered. 

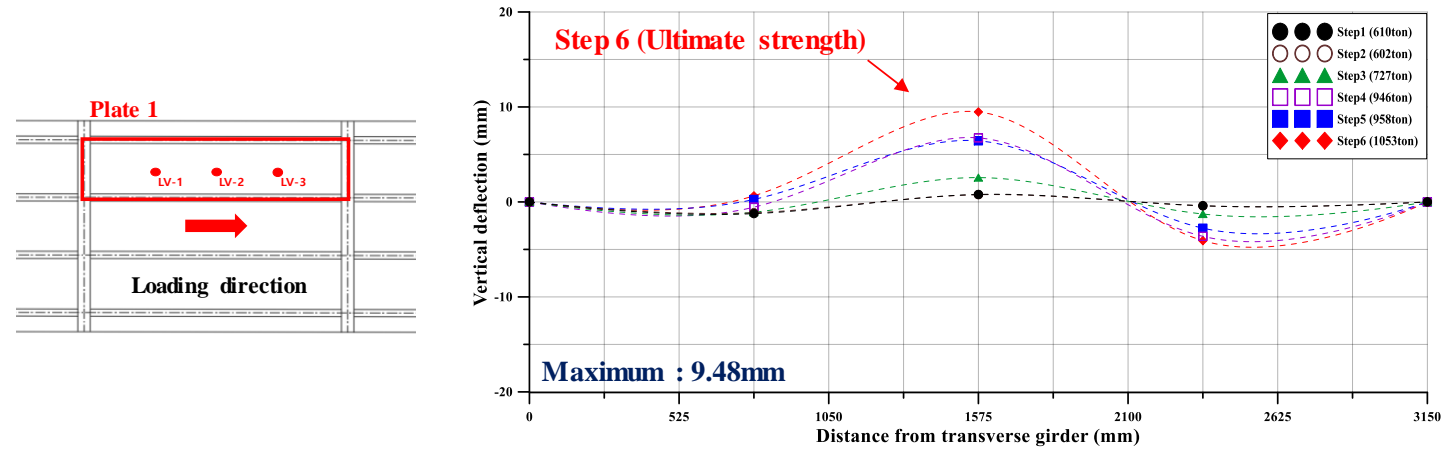

(a) Plate 1
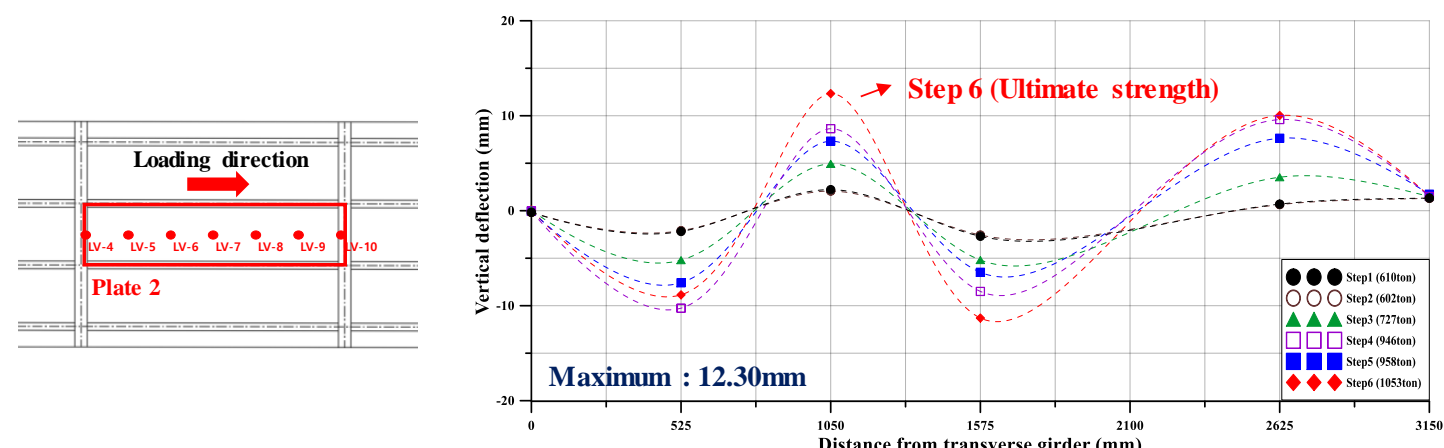

(b) Plate 2
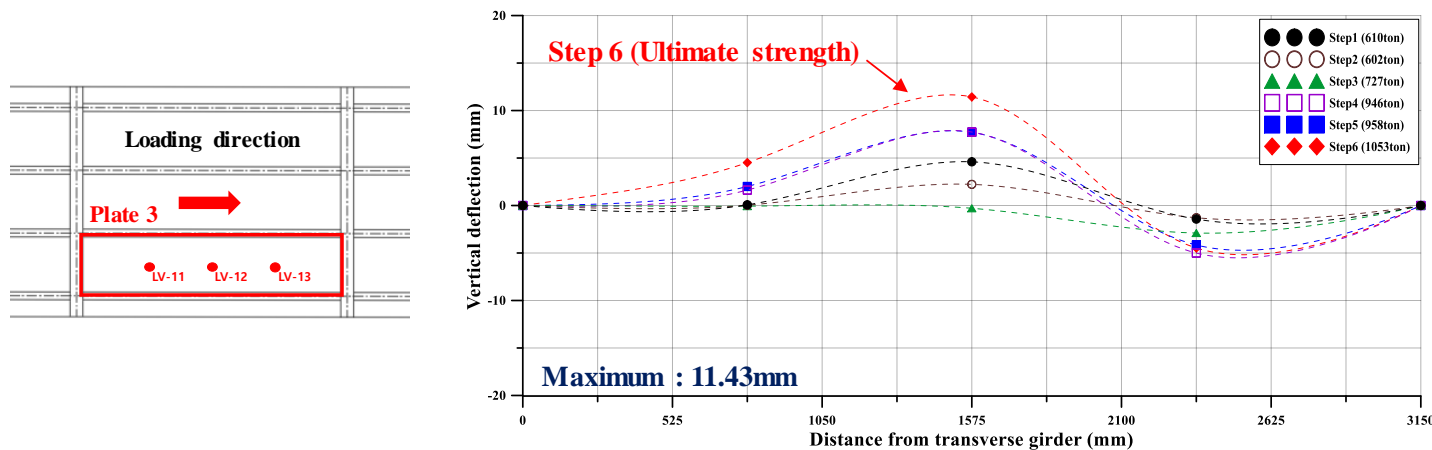

(c) Plate 3

Figure 18. Plate deflections of the tested structure at the maximum load of each step. 

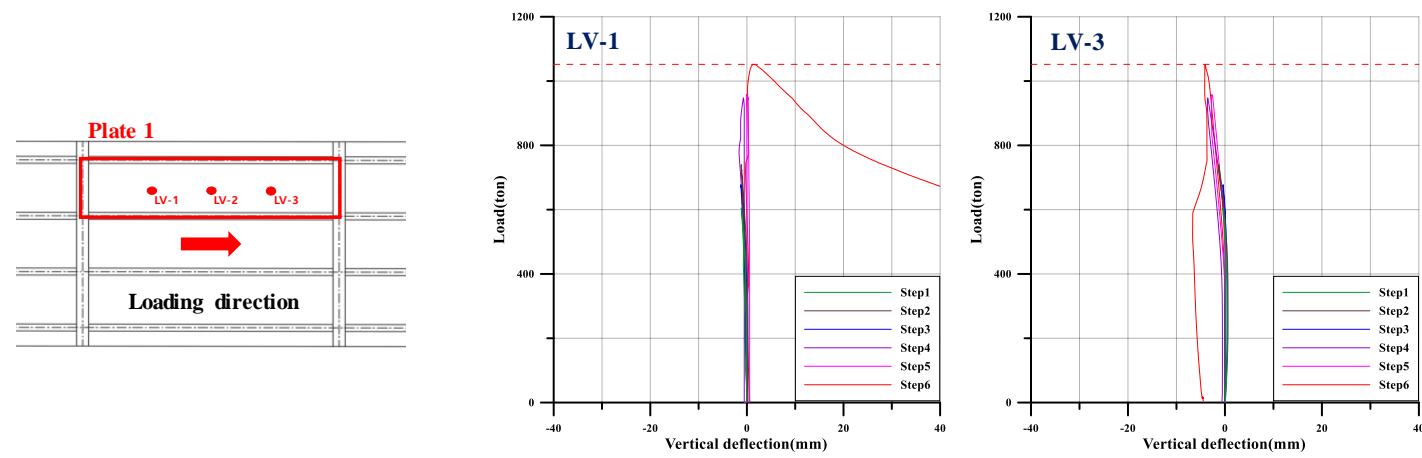

(a) Plate 1
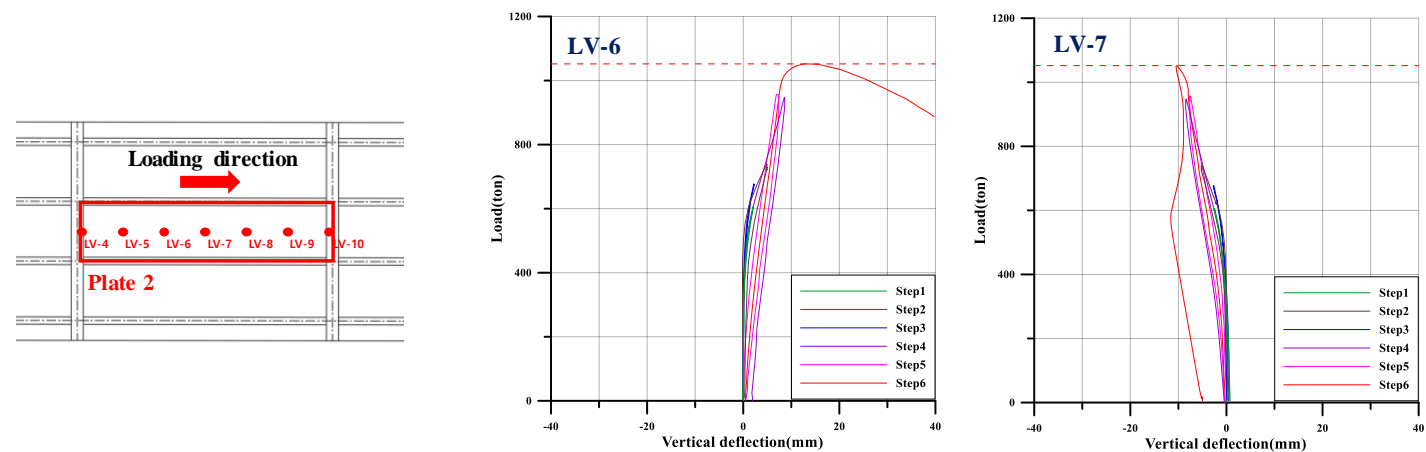

(b) Plate 2
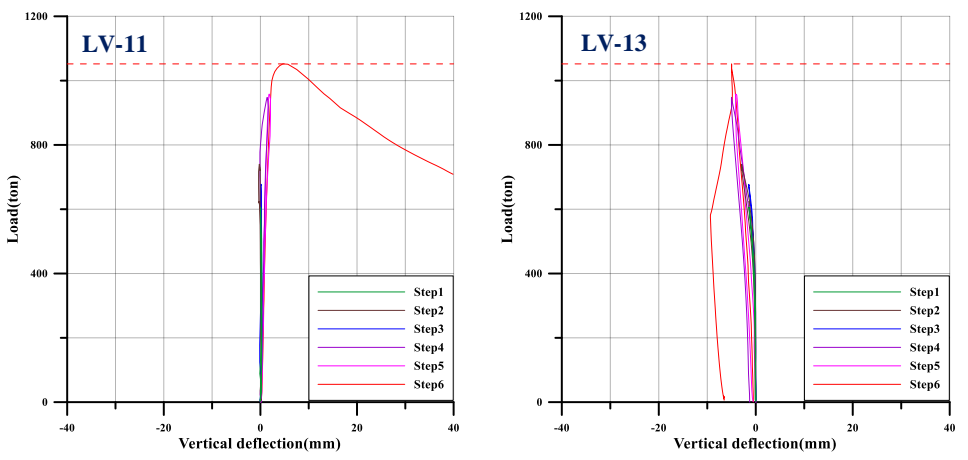

(c) Plate 3

Figure 19. Permanent plate deflections of the tested structure at each loading step.

Figure 20 shows the sideways deformation of a longitudinal stiffener at the maximum load of each step. The maximum deformation at the ultimate strength was $10.03 \mathrm{~mm}$. Figure 21 shows the permanent sideways-deformation of a longitudinal stiffener at each loading step. After the unloading process was completed at each loading step, the permanent sideways deformations of the stiffener were measured to be very small with less than $1 \mathrm{~mm}$. This reveals that the cyclic loading applied to the test structures does not affect the ultimate strength behaviour of stiffeners significantly. This is because the structure remained almost in elastic regime and the applied cyclic loads did not cause a significant accumulation of permanent (plastic) deformations as well as fatigue cracking during the repeated cycles of loading. 

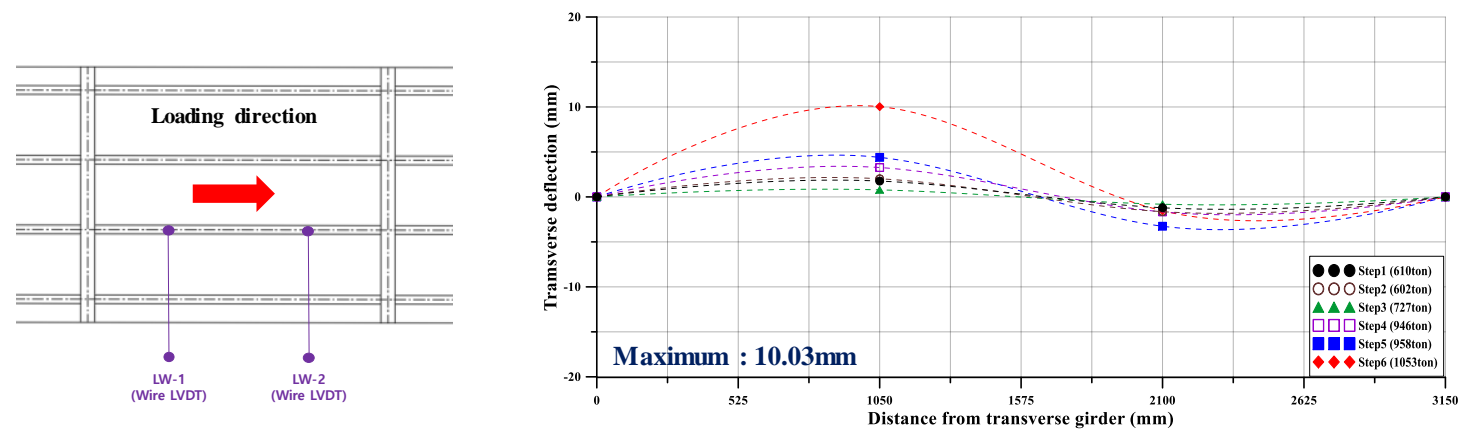

Figure 20. Sideways deformation of a longitudinal tiffener at the maximum load of each step.
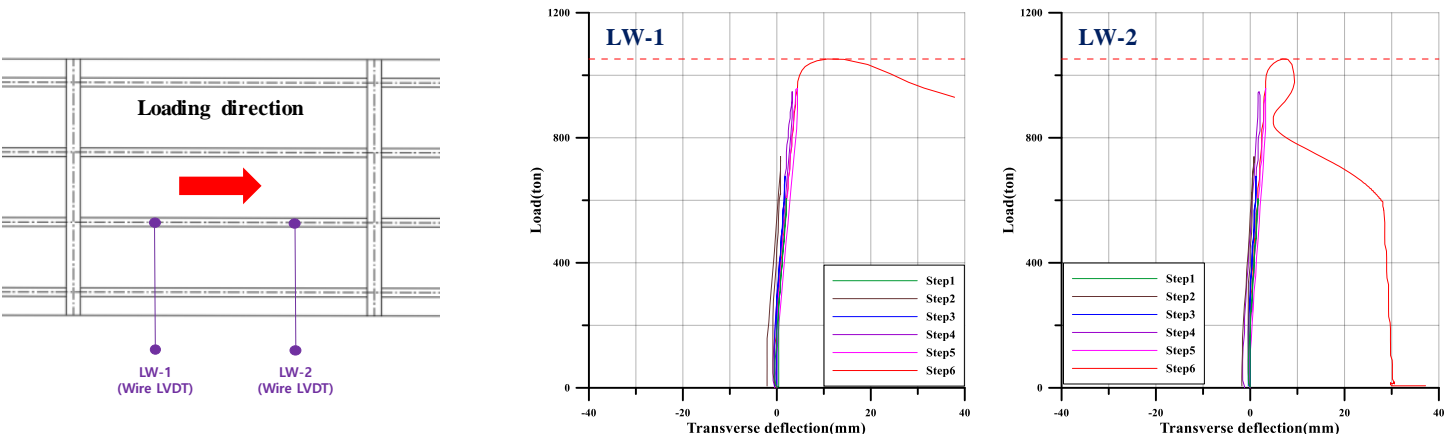

Figure 21. Permanent sideways-deformation of a longitudinal stiffener at each loading step.

\section{Concluding Remarks}

The aim of the paper was to obtain the test database on the ultimate limit states of a full-scale steel stiffened plate structure under cyclic axial-compressive loading. Based on the studies, the following conclusions can be drawn.

(1) A collapse testing was conducted on of a full-scale steel stiffened plate structure under cyclic axial-compressive loading in association with bottom plate panels of an as-built 1,900 TEU containership in whipping condition with a load ratio of tension to compression with $\mathrm{R}=0$.

(2) The welding-induced initial imperfections of the tested structure were measured using advanced technologies such as 3D laser scanner for plate initial deflections and X-ray diffraction method for residual stresses and reported in separate papers.

(3) Permanent plate deflections of the tested structure were very small after the unloading process was completed during the cyclic loading process, implying that the behaviour of plating remained almost in elastic regime as far as the cyclic loads were removed. No fatigue cracking was suffered in the tested structure. As such, the effects of cyclic axial-compressive loading on the ultimate strength of the tested structure were negligible.

(4) Permanent sideways-deformations of stiffeners were also very small after the unloading process was completed during the cyclic loading process, implying 
that the behaviour of stiffeners remained almost in elastic regime as far as the cyclic loads were removed.

(5) The tested structure was an assembly of plate elements and support members (longitudinal stiffeners and transverse frames), and thus items (3) and (4) mentioned above may lead to the conclusion that the effects of cyclic loads considered in the present study are negligible on the ultimate limit states of steel stiffened plate structures under cyclic axial-compressive loading as far as no cracking damage due to low cycle fatigue is suffered. It is however noted that this observation can differ for different types of cyclic load applications in magnitude and pattern as well as the number of cycles.

(6) It is hoped and believed that the test database obtained in the paper can be useful to validate computational models for the analysis of ultimate strength behaviour of steel stiffened plate structures under cyclic axial-compressive loading. It is one of benefits that the test database was obtained from a full-scale structure which can remove scale effects in association with various uncertainties due to fabrication and geometric or material nonlinearities.

\section{Acknowledgements}

This study was undertaken at the International Centre for Advanced Safety Studies / The Korea Ship and Offshore Research Institute (www.icass.center) which has been a Lloyd's Register Foundation Research Centre of Excellence since 2008. Part of the work was supported by the Swedish Research Council by the project "Fundamental research on the ultimate compressive strength of ship stiffened plate structures at Arctic and cryogenic temperatures", contract no. 2018-06864.

\section{ORCID}

Jeom Kee Paik: http://orcid.org/0000-0003-2956-9359

Jonas W. Ringsberg: http://orcid.org/0000-0001-6950-1864

\section{References}

[1] Paik JK. Ultimate limit state analysis and design of plated structures, 2nd Edition. John Wiley \& Sons; 2018.

[2] Paik JK. Advanced structural safety studies with extreme conditions and accidents. Springer; 2019.

[3] Hughes OF, Paik JK. Ship structural analysis and design. The Society of Naval Architects and Marine Engineers; 2013.

[4] Yao T, Nikolov PI. Buckling/plastic collapse of plates under cyclic loading. Journal of the Society of Naval Architects of Japan 1990;168:449-62.

[5] Goto Y, Toba Y, Matsuoka H. Localization of plastic buckling patterns under cyclic loading. Journal of Engineering Mechanics 1995;121:493-501.

[6] Usami T, Ge HB. Cyclic behavior of thin-walled steel structures-numerical analysis. Thin-walled Structures 1998;32(1-3):41-80. 
[7] Gordo JM, Guedes Soares C. Compressive tests on short continuous panels. Marine Structures 2008;21(2-3):113-37.

[8] Gordo JM, Guedes Soares C. Tests on ultimate strength of hull box girders made of high tensile steel. Marine Structures 2009;22(4):770-90.

[9] Gordo JM, Guedes Soares C. Compressive tests on stiffened panels of intermediate slenderness. Thin-walled Structures 2011;49(6):782-94.

[10] Lee PS, Noh HC. Inelastic buckling behavior of steel members under reversed cyclic loading. Engineering Structures 2010;32(9):2579-95.

[11] Cheng X, Chen Y, Pan L. Experimental study on steel beam-columns composed of slender H-sections under cyclic bending. Journal of Constructional Steel Research 2013;88:279-88.

[12] Lim WY, Lee D, You YC. Cyclic loading tests on exposed column-base plate weak-axis connections of small-size steel structures. Engineering Structures 2017;153:653-64.

[13] Li S, Hu Z, Benson S. An analytical method to predict the buckling and collapse behaviour of plates and stiffened panels under cyclic loading. Engineering Structures 2019;199. https://doi.org/10.1016/j.engstruct.2019.109627.

[14] Jagite G, Bigot F, Derbanne Q, Malenica Š, Sourne HL, Lauzon J, Cartraud P. Numerical investigation on dynamic ultimate strength of stiffened panels considering real loading scenarios. Ships and Offshore Structures 2019;14(1):374-86.

[15] Zhang X, Paik JK, Jones N. A new method for assessing the shakedown limit state associated with the breakage of a ship's hull girder. Ships and Offshore Structures 2016;11(1):92-104.

[16] Paik JK, Lee DH, Kim SJ, Thomas G, ma M. A new method for determining the design values of wave-induced hull girder loads acting on ships. Ships and Offshore Structures 2019;14(S1):S63-S90.

[17] ALPS/ULSAP. Ultimate strength analysis of plates and stiffened panels under combined biaxial compression / tension, edge shear and lateral loads. Greenboro, MD (USA): MAESTRO Marine LLC; 2019.

[18] ASTM E8/E8M-09. Standard test methods for tension testing of metallic materials. PA (USA): ASTM International; 2011.

[19] DNV-GL Rules for classification - ships, Part 2 Materials and welding, Chapter 4 Fabrication and testing. Høvik(Norway): DNV-GL; 2017.

[20] Yi MS, Lee DH, Lee HH, Paik JK. Direct measurements and numerical predictions of welding-induced initial deformations in a steel stiffened plate structure. Submitted for publication in Thin-Walled Structures 2019.

[21] Yi MS, Noh SH, Lee DH, Seo DH, Paik JK. Direct measurements, numerical predictions and simple formula estimations of welding-induced residual stresses in a steel stiffened plate structure 2019. Submitted for publication in Structures.

[22] Yi MS, Hyn CM, Paik JK. Full-scale measurements of welding-induced initial deflections and residual stresses in steel-stiffened plate structures. International Journal of Maritime Engineering, Transactions of the Royal Institution of Naval Architects 2018;160(A4):A397-A412. 
[23] Yi MS, Hyun CM, Paik, JK. An empirical formulation for predicting welding-induced biaxial compressive residual stresses on steel stiffened plate structures and its application to thermal plate buckling prevention. Ships and Offshore Structures 2019;14(S1):S18-S33.

[24] Le S, Benson SD. A re-evaluation of the hull girder shakedown limit states. Ships and Offshore Structures 2019;14(Sup1):S239-S250.

[25] Gannon LG, Pegg NG, Smith MJ, Liu Y. Effect of residual stress shakedown on stiffened plate strength and behaviour. Ships and Offshore Structures 2013;8(6):638-652.

[26] Quinton BWT, Daley CG, Gagnon RE, Colbourne DB. Guidelines for the nonlinear finite element analysis of hull response to moving loads on ships and offshore structures 2016;14(Sup1):S109-S114.

[27] Elsayed T, El-Shaib M, Gbr K. Reliability of fixed offshore jacket platform against earthquake collapse. Ships and Offshore Structures 2016;11(2):167-181.

[28] Ringsberg JW, Li Z, Tesanovic A, Knifsung C. Linear and nonlinear FE analkyses of a container vessel in harsh sea state. Ships and Offshore Structures 2015;19(1):20-30. 